\title{
Turning tumor inhibition into activation: engineering $T$ cells with chimeric signaling receptors
}

\author{
Ramona Schlenker $^{1 *}$, Matthias Leisegang ${ }^{2}$, Wolfgang Uckert ${ }^{2,3}$, Elfriede Noessner ${ }^{1}$ \\ From Society for Immunotherapy of Cancer 29th Annual Meeting \\ National Harbor, MD, USA. 6-9 November 2014
}

Poor in vivo persistence and loss of function of adoptively transferred $\mathrm{T}$ cells in the tumor milieu are known shortcomings of adoptive T cell therapy (ATT). Providing costimulation might help to improve ATT efficiency. However, human CD8 T effector cells are largely CD28 negative and most tumors do not express CD80 or CD86, thus costimulation cannot be provided via $\mathrm{CD} 28$ ligation. We propose to facilitate costimulation of CD8 $\mathrm{T}$ effector cells in the tumor milieu through engineering of $\mathrm{T}$ cells with a chimeric signaling receptor, which can turn tumor mediated inhibition into activation by abrogating inhibitory PD1 signaling with concomitant activation of the costimulatory pathway. Human $\mathrm{T}$ cells engineered to express melanoma specific $\mathrm{T}$ cell receptors (TCR) plus the chimeric signaling molecule showed higher ERK phosphorylation associated with stronger IL-2 and IFN- $\gamma$ secretion upon co-culture with PD-L1 positive target cells. T cells expressing a low avidity TCR achieved functional responses comparable to high avidity TCRs when engineered with the chimeric receptor. The chimeric receptor did not only increase cytokine secretion in vitro, but importantly, also supported intra-tumoral proliferation of $\mathrm{T}$ cells in a humanized mouse melanoma model.
doi:10.1186/2051-1426-2-S3-P248

Cite this article as: Schlenker et al:: Turning tumor inhibition into activation: engineering T cells with chimeric signaling receptors. Journal for ImmunoTherapy of Cancer 2014 2(Suppl 3):P248.

\section{Authors' details}

'Institute of Molecular Immunology, Helmholtz Center Munich, German Research Center for Environmental Health, Munich, Germany. ${ }^{2}$ Max Delbrück Center for Molecular Medicine, Helmholtz Association, Berlin, Germany. ${ }^{3}$ Institute of Biology, Humboldt-University, Berlin, Germany.

Published: 6 November 2014

Institute of Molecular Immunology, Helmholtz Center Munich, German Research Center for Environmental Health, Munich, Germany

Full list of author information is available at the end of the article

Submit your next manuscript to BioMed Central and take full advantage of:

- Convenient online submission

- Thorough peer review

- No space constraints or color figure charges

- Immediate publication on acceptance

- Inclusion in PubMed, CAS, Scopus and Google Scholar

- Research which is freely available for redistribution 